\title{
An Adult Education Model of Resident Participation: Building Community Capacity and Strengthening Neighborhood-Based Activities in a Comprehensive Community Initiative (CCI)
}

\author{
Daniel Brisson \\ Susan Roll
}

\begin{abstract}
Comprehensive Community Initiatives (CCIs) are of growing interest to social work and the social services field as they are an effort to move away from remediation of individual problems within neighborhoods to a comprehensive change effort that builds resident and institutional capacity for long term sustainability of healthy communities. Built on ongoing lessons learned from the community development field, CCIs are largely foundation supported projects that engage low-income neighborhood residents in a holistic change effort. However, based on what is known about community organizing, CCIs will likely face challenges as long as they involve a top-down approach with an outside funder entering a community to make change. This manuscript frames an adult education model of resident participation that can be used in CCIs and provides a case example illustrating the model in action. A discussion of how the model can be an effective means for communities to take advantage of outside resources while maintaining their power and voice for change is offered in conclusion.
\end{abstract}

Keywords: Adult education; community development; community capacity; comprehensive community initiative; resident participation

The War on Poverty was first declared by President Johnson in his State of the Union address in January of 1964 . Yet today, 37 million people in the US remain in poverty (US Census Bureau, 2007). Poverty is associated with, and confounded by, a number of social issues including high crime, unemployment, poor health and educational outcomes, homelessness, substance abuse, and juvenile delinquency (Booth \& Crouter, 2001; Brooks-Gunn, Duncan, \& Aber, 1997). The disproportionality of families living in poverty by race, ethnicity and legal status further complicate this complex dynamic (Massey, 1990; Quillian \& Redd, 2006; Wilson, 1987).

In addition to the vast social impacts, poverty has far reaching policy implications including financial responsibilities from local, state and federal sources, housing, welfare and publicly funded health insurance programs (Jencks \& Mayer, 1990; JoassartMarcelli, Musso, \& Wolch, 2005; O’Conner, 1999; Wilson, 1987). The illumination of the depth of the problem that was brought forth in the 1960s has been tempered by political and social battles over welfare expenditures, undocumented immigrants and "family values." With such far reaching implications, notwithstanding the moral and ethical obligations of the wealthiest nation in the world to care for its citizenry, it is of critical import that social scientists work cooperatively with policy makers, private funders, communities, and social work practitioners to address issues related to poverty.

Daniel Brisson, Ph.D., is an assistant professor and Susan Roll, MSW, is a doctoral candidate in the Graduate School of Social Work at the University of Denver.

Copyright (C) 2008 Advances in Social Work Vol. 9 No. 2 (Fall 2008), 157-175 
In response to the multiple issues facing families in impoverished neighborhoods, practitioners have attempted varied community development initiatives aimed at improving outcomes for low-income community members (Annie E. Casey Foundation, 2007; DeSouza Briggs \& Muller, 1996; Rohe, Bratt, \& Biswas, 2003). The most recent approach is the Comprehensive Community Initiative (CCI). CCIs are an effort at addressing, in a comprehensive way, the myriad issues facing families in low-income neighborhoods, typically by bringing together community leaders, and the varied organizational and governmental stakeholders to work for common community solutions.

On the surface, and based on what is known about community organizing, the success of CCIs will be partly based on an initiative's ability to navigate the tension between resident participation and a top-down approach of an outside funder entering a community to make change. There are examples from across the country of well-meaning philanthropies and foundations investing money in a community only to see that the power differential, the lack of community buy-in, and the differences in culture and values present obstacles that the project cannot overcome (Brown \& Fiester, 2007). We suggest, however, that through the careful development of resident participation, CCIs can be an effective way for communities to take advantage of outside resources while still maintaining their power and voice for change.

Resident participation, a cornerstone of CCIs, is critical for building community capacity and neighborhood-based initiatives (Annie E. Casey Foundation, 2007). Resident participation allows community change efforts to sustain healthy communities over time. One of the most clearly articulated and applicable theories for resident participation can be found in the field of adult education. Although multiple definitions of adult education can be found in the literature, it generally refers to the development and acquisition of knowledge by adults through both formal and informal methods that bring about changes in attitudes and behaviors that in turn affect both the individual and society (Selman, Selman, Cooke, \& Dampier, 1998). Because adult education is voluntary, those who participate are generally highly motivated. In addition, particularly when it involves learning skills through community engagement, adult education has a benefit for both individuals and the community as a whole.

What is unique about this presentation is two-fold. One, although adult education has made significant contributions to the field of social work and community development, the linkages have not been made explicit. CCIs are a growing resource for communities; however, if resident participation through adult education is not carefully developed, neighborhoods will not be successful in capturing this valuable resource. As was seen in the Model Cities project of the 1960s, money alone is not the answer for community change. Meaningful resident participation cannot be assumed. A thoughtful and often time consuming process of resident engagement is critical. Second, this manuscript offers a prescription, using a specific case example, for engaging residents in change. While activists and academics alike hail resident participation as tantamount to creating meaningful change, often this charge is not articulated in a practical model that can be applied by practitioners. 
The contribution of this manuscript is to provide a concise and practical model of resident participation that can be used in CCIs as well as other community change efforts in marginalized communities. The model is informed from the well developed literature on adult education, with a focus on critical learning, citizenship, and civil society (Johnston, 1999; Mezirow, 1996; Welton, 1997). The manuscript begins with a discussion of adult education in the context of critical learning theory as a rationale for a resident participation model. Then, a detailed description of CCIs as a holistic community change strategy to address the multitude of urban poverty issues is offered. An adult education model of resident participation is then presented with case examples at every stage illustrating the practical application of the conceptual model. A critique and implications are considered in conclusion.

\section{RATIONALE FOR RESIDENT PARTICIPATION}

Resident participation, at its best, is the voluntary gathering of individuals and groups with the intention of making positive change on specific issues for improved quality of life for the entire community (Gamble \& Weil, 1995). Although resident participation is an essential component of a CCI, the CCI literature does not address the development of resident participation as does the adult education literature using language such as critical learning theory (Brookfield, 2005; Mezirow, 1996), citizenship (Johnston, 1999; Welton, 1997), and civil society (Gramsci, 1986). Also known as "lifelong learning” (Johnston, 2000), adult education forms the conceptual underpinning of resident participation. Johnston (2000) articulates it well when he says, "one of the most important agendas for lifelong learning is education for active citizenship” (p.22).

In the development of critical learning theory, adult educators have long recognized issues of power and control in civic engagement as well as the promise of positive outcomes when community members are actively involved in decision-making through a process of critical reflection. Brookfield (2005) suggests that fully integrating several different types of learning such as reflexive learning, evolutionary learning, and communicative action into community change efforts is the necessary component to overcome innate issues of power, particularly in disadvantaged communities. Critical learning theory's focus on free and open communication allows adult learners to confront issues of power and also allows for the exploration of multiple types of learning.

A leading scholar on critical learning, Mezirow (1996) addresses the issue of the critical self-reflection of assumptions. This is particularly important in diverse communities and where an outside agency is coming in to make change. Presuppositions and prejudices commonly get in the way of progress. Here, each individual involved in the process, from the facilitators to the resident participants, must be meaningfully engaged in the change effort. Drawing on the writings of Habermas, Mezirow (1996) outlines the specific conditions under which members are free to participate in change efforts, including an open and inclusive environment in which each individual is free to discuss and question without judgment, the encouragement and space to critically reflect and share differing views and opinions, and the ability to come to a consensus that is informed and objective. 
Citizenship is another prominent theme in the adult education literature which underscores the importance of resident participation. Johnston (1999), in his discussion of citizenship and social purpose adult education, suggests a framework for adult learning through citizenship that includes both reflective citizenship, e.g. critical learning and active citizenship where individuals are involved in community change efforts. Welton (1997) and others (Hill, 1994; Mayo 1997; Newman, 1995) also illustrate citizenship as a crucial component of social change as individual learners become invested in the betterment of their community.

Finally civil society, made up of social, voluntary and non-government organizations provides a context for adult learning through social change efforts. It is precisely this absence of government in the context of civil society that allows adult learners to have power to make change (Gramsci, 1986). Many examples of change efforts by traditionally disempowered groups are seen in the context of civil society (Johnston, 1999).

Particularly in the realm of civil society, issues of race, class, gender and ethnicity play key roles in defining power structures that either create or inhibit change. For example, Nesbit (2006) suggests that while it has been missing from conversations of adult learning, social class clearly plays a central role in power dynamics and social strata. He shows that this context influences education and education, in turn, affects the broader social arena. Civil society is the arena in which social change through adult learning can flourish. Different from government, this realm of society is ideally free from structured power and thus can create power based on equality and inclusivity. Although no community is totally free from the many pitfalls of power differences, successful and sustainable change in low-income neighborhoods will only come from within this context.

\section{RESIDENT PARTICIPATION IN A CCI}

Resident participation in CCIs presents a unique situation that calls for critical thinking about participation strategies and stages. Residents are likely to participate in an externally funded project only if they are included in goal development, planning and implementation of activities. Typically, resident participation is mobilized through a grassroots effort around a common issue or concern. For CCIs however, there is a basic difference from classic grassroots community change efforts. Namely, initiators of CCIs are likely to be philanthropic foundations often in partnership with local governments or with some set of local organizations as partners for change. Therefore, rather than the gradual process of building resident participation, or the militant mobilization against a clear neighborhood foe, residents of communities which may be "targeted" for CCIs face a complex set of potential benefits as well as likely risks.

\section{What is a CCI?}

CCIs are largely foundation supported projects that engage low-income neighborhood residents in a holistic change effort. CCIs have extended from the 
Community Development Corporation (CDC) movement in the 80s and 90s (Glickman \& Servon, 1998; Rohe, 1999; Rohe et al., 2003). The CDC movement attempted to address issues faced by families in low-income neighborhoods by focusing on housing needs. As numerous additional needs became apparent, CDCs took on the tasks of community organizing and business development in neighborhoods, broadening and addressing multiple issues in low-income neighborhoods (Glickman \& Servon, 1998; Rohe, 1999). The broadening of the CDC mission spurred the development of CCIs as the next wave of interventions in low-income communities. According to the Aspen Institute's Roundtable on Community Change, there are at least 16 CCIs with participation from over 50 communities around the country (Roundtable on Community Change, 2008).

Most often funded through philanthropic organizations, but occasionally by government bodies, CCIs promote change at the individual, neighborhood and systems level (Aspen Round Table, 1995). This change is realized through the development of both community capacity and a set of comprehensive, neighborhood-based activities that permeate through physical, social, and economic sectors (Aspen Round Table, 1995; Kubisch, 1996). Key to capacity building in the neighborhood is genuine participation by residents in the community change effort and thus resident participation becomes a fundamental building block of social change in low-income communities (Aspen Round Table, 1995; Kubisch, 1996).

\section{Resident Participation Applied to a CCI Framework}

Figure 1 illustrates how resident participation is applied to the CCI framework. According to the model, resident participation is the essential element for the development of both community capacity and neighborhood-based activities - which together result in the success of CCIs. As articulated in the CCI literature, the development of both community capacity and neighborhood-based activities then produces improved outcomes at the individual, neighborhood, and system levels (Kubisch, Auspos, Brown, Chaskin, Fulbright-Anderson, \& Hamilton, 2002). 


\section{FIGURE 1. Resident Participation Applied to a CCI Framework}

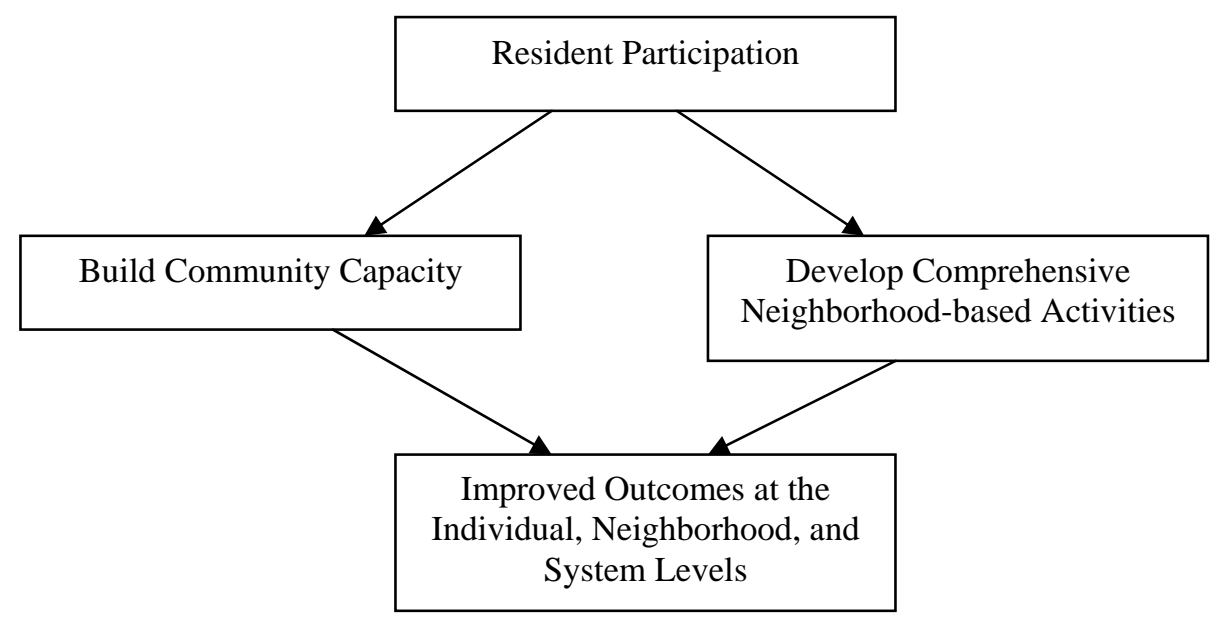

The development of community capacity is the first essential element for improved outcomes for families. Like similar concepts of social capital (Coleman, 1988; Putnam, 2000) and collective efficacy (Sampson, Raudenbush, \& Earls, 1997), community capacity is realized through the actions and interactions of individuals, organizations, and networks of a community (Bowen, Martin, Mancini, \& Nelson, 2000). Chaskin (2001) defines community capacity as "the interaction of human capital, organizational resources, and social capital existing within a given community that can be leveraged to solve collective problems and improve or maintain the well-being of a given community. It may operate through informal social processes and/or organized effort” (p. 295). Chaskin goes on to note that differences in community capacity can affect safety, economic opportunities, health and educational outcomes and the general quality of life for individuals and families.

In his framework, Chaskin (2001) defines the fundamental characteristics of community capacity. First is a sense of community where members share values, norms and vision that allow them to work together for a collective purpose. Second is a level of commitment where people see themselves as part of a community and are willing to participate in activities for the betterment of the community. Third is the ability to solve problems, which Chaskin emphasizes as a key to community capacity. It is through the ability to solve problems that ideas and concepts are turned into action. Fourth and finally, Chaskin identifies access to resources which include human, physical, political, and economic, from both community resources as well as outside resources, as a fundamental aspect of community capacity. These four building blocks of community capacity are reflected in adult education discussions of critical learning, citizenship, and civil society.

The second critical component for supporting improved outcomes for families is the development of comprehensive neighborhood-based activities. This happens in two ways. First is an attempt to build on the strengths that already exist in the community. Second is 
the identification and implementation of services where the neighborhood has needs (Kubisch, et al., 2002). While community work, until recently, focused on remediation of specific problems, for example housing, health or education, the CCI movement is an attempt at a more comprehensive approach to neighborhood improvement. This comprehensive approach frees an initiative from the constraints of categorical aid to communities and allows for pursuit of opportunities as they present themselves (Aspen Round Table, 1995), building on community strengths, and filling in service gaps.

Problematic in the CCI model is an inattention to the developmental process of resident participation. Despite the best intentions, establishing trust and building participation that is broadly based among residents and institutions in neighborhoods cannot be assumed (Brown \& Fiester, 2007). Adults in many low-income neighborhoods have justifiably become very skeptical of "outsiders" who seek community change (Kretzmann \& McKnight, 1993; Medoff \& Sklar, 1994). There are noticeable failures among community change efforts to "maintain" participation when adults feel they are used only to "sign off" but not to influence directions of plans and change (Twelvetrees, 1996). Residents of low-income communities have all too often engaged in work for neighborhood improvement or development, only to find that there were strict limits on opportunities for participation, or that their engagement was seen only as an entry into the community rather than an authentic step towards partnership. To address this oversight, an adult education model of resident participation is now offered. A case example for each of the stages is offered to illustrate the practical application of the model.

\section{AN ADULT EDUCATION MODEL OF RESIDENT PARTICIPATION}

Figure 2 is an adult education model of resident participation built on theory and past practice successes, designed specifically for implementation in a CCI. Table 1 details in tabular format the specific contributions of each stage.

As seen in Figure 2 and informed by critical learning theory, action and learning pervade every developmental stage of resident participation. It is through action and learning that residents build skills and confidence that can lead to sustainable community change (Mezirow, 1996). Action is necessary for change to take place, while learning is necessary to move the developmental process from one stage to the next. Although Figure 2 can be viewed as a linear process, it is important to keep in mind the constant activities of action and learning taking place concurrently, empowering both individuals and the community. Thus, resident participation develops both by moving down the developmental model in stages, and through feedback loops, created through the process of action and learning, that can move residents back up to a previous stage of the model. 


\section{FIGURE 2: $\quad$ An Adult Education Model of Resident Participation}

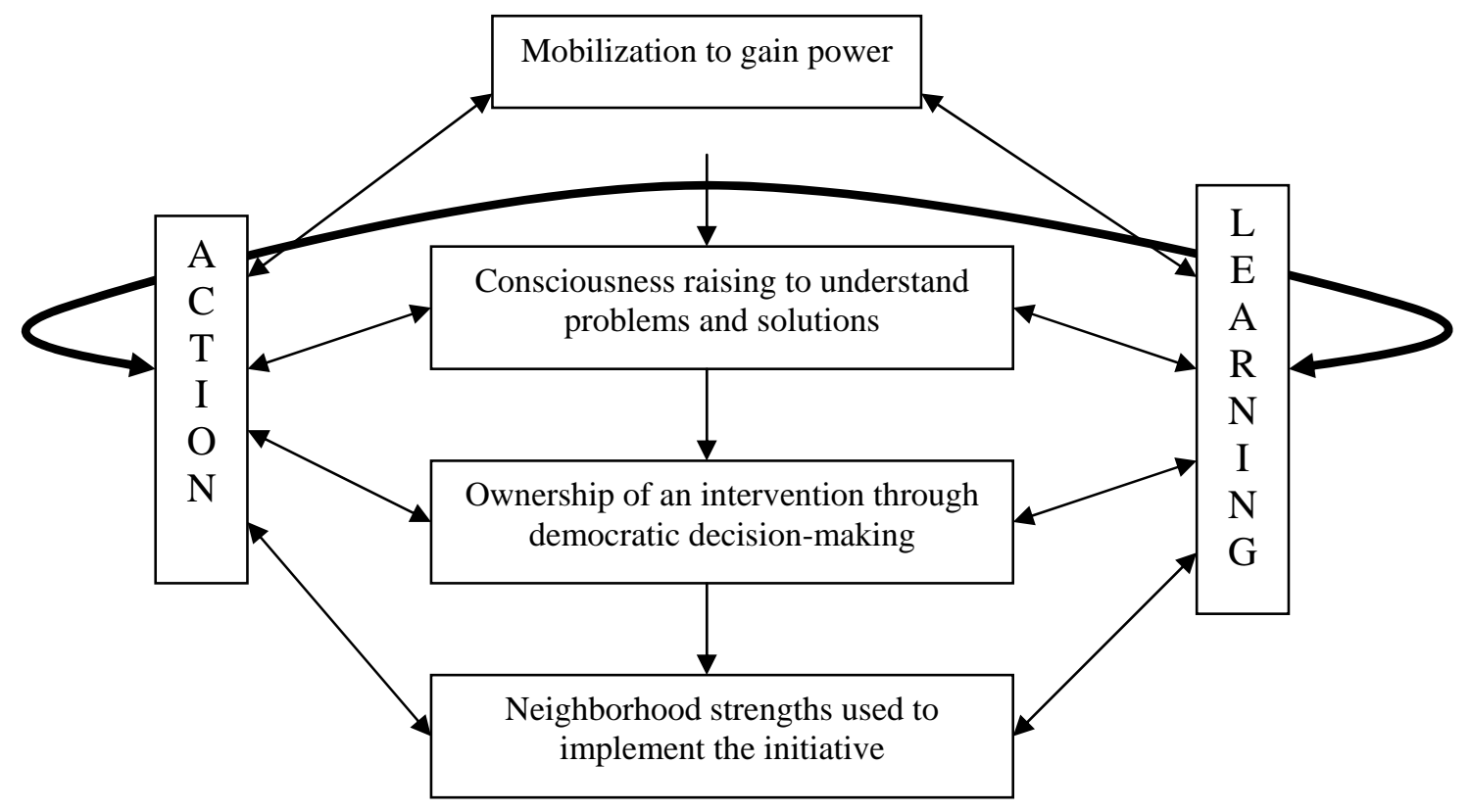

Successfully navigating the potentially problematic power differential is critical to the success of a CCI. In a CCI, a necessary precursor to mobilization is a funding source for community development, but often a crisis that demands community action stimulates the change process. In either scenario, the process for engagement in participation needs an early focus on mobilization of the members within the community in response to the unequal power between an external funder and the community residents. Here adult education plays a key role in managing the unequal distribution of power (Cervero \& Wilson, 1994). 
TABLE 1: An Outline of the Model and Contributions at Each Stage

\begin{tabular}{|c|c|}
\hline $\begin{array}{l}\text { Characteristics of the } \\
\text { participation model }\end{array}$ & $\begin{array}{l}\text { Contribution to the development of community capacity } \\
\text { and neighborhood-based activities }\end{array}$ \\
\hline Action and learning & $\begin{array}{l}\text { - Refines action and interaction skills of community } \\
\text { members } \\
\text { - Builds problem solving skills }\end{array}$ \\
\hline Mobilization to gain power & $\begin{array}{l}\text { - } \text { Builds a sense of community } \\
\text { - Develops networks of relationships } \\
\text { - } \text { Provides access to resources } \\
\text { Builds a representative forum for decision-making }\end{array}$ \\
\hline $\begin{array}{l}\text { Consciousness raising to } \\
\text { understand problems and } \\
\text { solutions }\end{array}$ & $\begin{array}{l}\text { - } \text { Reveals hidden resources } \\
\text { - } \text { Builds a sense of community } \\
\text { - } \text { Develops networks of relationships } \\
\text { - } \text { Builds problem solving skills } \\
\text { - } \quad \text { Fevelops trust } \\
\text { Facilitates commitment of community members }\end{array}$ \\
\hline $\begin{array}{l}\text { Ownership of an intervention } \\
\text { through democratic decision- } \\
\text { making }\end{array}$ & $\begin{array}{l}\text { - Builds a sense of community } \\
\text { - Develops trust } \\
\text { - } \text { Facilitates commitment of community members } \\
\text { - Builds problem-solving skills }\end{array}$ \\
\hline $\begin{array}{l}\text { Neighborhood strengths used to } \\
\text { implement the initiative }\end{array}$ & $\begin{array}{l}\text { - Facilitates commitment of community members } \\
\text { - Builds problem-solving skills } \\
\text { - } \quad \text { Provides access to resources }\end{array}$ \\
\hline
\end{tabular}

\section{Stages of the Participation Model Illustrated with a Case Example}

The specific stages of the participation model are described in detail and illustrated using a case example from the authors' work as consultants with a CCI. The case example comes from work done, primarily in one city, as part of the Annie E. Casey Foundation's Making Connections initiative. Making Connections is a ten year comprehensive community initiative in ten cities around the country. ${ }^{1}$ An explicit goal of Making Connections is to fully engage residents in the initiative. From the authors' experiences, Making Connections achieved many successes in garnering resident participation. However, there were also instances were obstacles to resident participation were not overcome. We will illustrate the stages of the participation model through case

\footnotetext{
${ }^{1}$ For more information see http://www.aecf.org/MajorInitiatives/MakingConnections.aspx.
} 
examples of both successes and obstacles experienced during our work with Making Connections.

\section{Stage 1: Mobilization to Gain Power}

The first developmental stage of the resident participation model is mobilization to gain power. Mobilization is a process that was popularized by community organizers during the protest movements of the 1960s, and is used to build community capacity (Alinsky 1971; Kahn, 1995; Weil \& Gamble, 1995). Mobilization occurs when residents of a community are acting as one unit and often results in a group working for a common cause. Mobilization may start simply as a group of residents meeting about an issue, but could culminate in a mass of people using their collective numbers to right unequal power structures and influence decision-making. This process is particularly salient in low-income communities where collective action is used in lieu of other resources to acquire power. Collective action then becomes the power source for the previously powerless community (Cervero \& Wilson, 1999).

For multiple reasons, mobilization is the building block of the resident participation model. Mobilization will develop community capacity by generating a sense of community, and begin to develop a community's network of relationships. Also, mobilization allows for a representative forum in community problem solving and decision-making. Mobilization may also maximize the resources available to the community.

Mobilization, at its most powerful, involves the full participation of the community. To truly develop a comprehensive initiative the input of the full range of stakeholders is vital. Therefore, the entire community must be mobilized. If certain residents of the community are not participating, then there is danger that needs are not being met in the comprehensive set of activities. Mezirow (1996) argues that meaningful discourse can only come as result of full participation through solidarity of the community. This does not mean that every individual must agree, but they must be committed to making change together. This has been well demonstrated in the literature (Castelloe, Watson, \& White, 2001; Freire, 1994; Rubin, 2000; Schleifer, 1991; Wilkinson \& Quarter, 1995).

In one Making Connections site, community organizations were successfully brought together as partners to mobilize residents. One of the organizations, Metro Organizations for People (MOP), specialized in mobilizing community residents. MOP's ability to mobilize is partially based on the trusting network of residents they have successfully organized in the past. Thus, when mobilization becomes necessary there is already a network on which to build. The main element of MOP's mobilization strategy is twofold. The first is to spread the word. This is done not simply through hanging flyers and posting public notices in newspapers to bring together a neighborhood force, but involves one-to-one, in person contact with community members. MOP participants and volunteers, as neighbors and members of the community, are asked to make one-to-one contact within the neighborhood with the goal of sharing information and eliciting support. Each MOP members is given a minimum number of residents to contact in these one-to-one opportunities in an effort to reach the greatest number of people. For example, 
recently, following a promise by Denver's mayor to provide scholarships to all high school graduates from one of the poorest performing middle schools in the city, MOP organizers conducted over 250 face-to-face visits with middle school families to educate and secure pledges of students' commitment to graduate from high school.

Although the Making Connections site was successful in bringing together organizational partners, Making Connections never fully utilized MOP's mobilizing skills to bring together a resident group to support the CCI. Instead, MOP was simply brought to the table as a partner organization with other partner organizations. Using the case example, one can conclude that Making Connections was successful in mobilizing organizations, but unsuccessful in organizing residents. By not utilizing MOP's skills and experience in organizing residents, Making Connections did not fully mobilize the community - a mistake that is exacerbated when examining future stages of the model.

\section{Stage 2: Consciousness Raising to Understand Problems and Solutions}

The second developmental stage of the residential participation model is consciousness raising to understand problems and solutions. Consciousness raising is a process in which members of a community come together to share their individual concerns, and through sharing and active listening, come to understand the root causes of individual issues. These root causes often are embedded in community issues that the mobilized community can address. Consciousness raising is a powerful emancipation exercise from the adult learning tradition (Freire, 1994).

Consciousness raising begins with an understanding of the social, political, and economic inequities in a system that contribute to individual and collective poverty, and disempowerment. Once this awareness has been achieved, an action step to right the unequal system can take place. According to Freire, liberation from poverty can only occur through consciousness raising followed by action by the poor themselves. It would be a basic contradiction for liberation from poverty to occur through policies generated through an oppressive system. In the participation model presented here, consciousness raising occurs seamlessly through the introductions, encounters, meetings, and relationships that develop through the mobilization process. The empowerment of both individuals and the community continues at this consciousness raising stage as ideas are shared, information is revealed, and insights are developed through the learning process (Mezirow, 1996; Wilkinson \& Quarter, 1995).

While one Making Connections site was successful in mobilizing partner organizations, the site did not mobilize residents and therefore had no opportunity to successfully engage in consciousness raising of the full community. Further, other than bringing partner organizations together for meetings, there was no explicit effort made to have partner organizations share stories and ideas to reach a collective understanding for the community. The result was the familiar organizational strategy of crossorganizational meetings dictated by self-interest, and struggles over limited power within the new CCI. 
Interestingly, partner organizations from the Making Connections site have tools available to engage in community consciousness raising. In fact a Story Circle Toolkit was developed by Making Connections partner organizations for precisely this reason. ${ }^{2}$ Unfortunately, the toolkit was only used in small constituent groups to address isolated issues, and never to develop full participation for the CCI. Using the participation model as a guide, it would first be important to fully mobilize residents so that outcomes from the story circles would be representative of the full community.

\section{Stage 3: Ownership of an Intervention through Democratic Decision-Making}

The third developmental stage of the resident participation model is ownership of the initiative through democratic decision-making. The first part of this stage, ownership, refers to the meaningful participation in the development of the initiative. One way that this has been framed in the field of adult education is through Participatory Action Research (PAR) (Fals-Borda \& Rahman, 1991; Freire, 1994; Leach, 1994; McTaggart, 1997; Sarri \& Sarri, 1992). PAR is a research and evaluation methodology where subjects are considered experts on the topic and inform programmatic and research decisionmaking. Through PAR community dialogue and critical consciousness serve to empower individuals and communities, develop individual change, and drive collective action (Leach, 1994; McTaggart, 1997; Sarri \& Sarri, 1992). Research shows that community development initiatives experience resistance when community members do not feel included, do not have power, are not given access to information, and are not active participants in the change process (Lewin, 1946; Sarri \& Sarri, 1992).

In addition to ownership, the third stage of the resident participation model involves democratic decision-making. As defined by Jefferson and Tocqueville, participatory democracy invites participation in decision-making by all members of the community (Schleifer, 1991). Although democracy is practiced in many forms (Thompson, 1976), the use of participatory democracy is emphasized in this model because of its strengths that include: the opportunity for equal participation by all, the opportunity for true consensus on decisions, and the inclusion of dissenting and minority opinions. As quoted by Brookfield (2005), to Habermas, democracy is "the adult leaning project of the contemporary era” (p.1130).

An inherent issue in ownership of the intervention and democratic decision-making is the notion of power. One site from the Making Connections initiative valiantly struggled with the issue of power in trying to take ownership of the intervention and trying to consistently enact a democratic decision-making structure. The site's struggles are illustrated at two different points in the initiative. The first point was at the introduction of the initiative. Implied in a foundation initiated program is ownership by the foundation. To transfer ownership of the initiative, the funder talked openly about their desire for true resident participation. The funder used jargon such as 'authentic demand' to describe how the goals of the initiative were to come from the community and not the

\footnotetext{
${ }^{2}$ The toolkit is available publicly at http://www.makingconnectionsdenver.org/publications/uploads/66/StoryCircleToolkit.pdf
} 
foundation. However, the foundation had a model for success that was informed by high profile experts in the field and this model was a major driver in programmatic decisionmaking. Further, the foundation board had an outcome agenda for the initiative, which often competed with the authentic demand from the community. Resident participants from this Making Connections site were successful in 'pushing back' and scoring some 'wins' from the foundation, but it was always clear to participants at the site that the agenda of the foundation needed to be a high priority.

One of the 'wins' for this Making Connections site was establishing a communitydriven learning group, as opposed to a community-based learning group. However, even in establishing the community-driven group, issues of power interfered with ownership and the democratic-decision-making of the group. Our role in the group was as outside consultant and expert. As an 'expert' we often struggled to know when it was appropriate to use expertise to inform the decision-making of the community-driven group. Ultimately, it was the trusting relationship with community members that allowed us to successfully navigate the often confusing role that the group wished us to fill.

In our experience the issue of power places serious obstacles in front of successfully establishing ownership of an intervention through democratic decision-making in the participation model. These obstacles are not easily overcome, and may need to be resolved through an upward movement in the participation model, specifically by repeating the consciousness raising stage. From our experience, ownership does not happen quickly but is built over time through incremental wins, the building of trust, and gradual transformation.

\section{Stage 4: Neighborhood Strengths Used to Implement the Initiative}

The final developmental stage of the resident participation model is using neighborhood strengths to implement the initiative. From this perspective the individuals and the community are not viewed in terms of deficit areas but instead in terms of their strengths (Kretzmann \& McKnight, 1993; Saleebey, 1997; Weick, Rapp, Sullivan, \& Kisthardt, 1989). For example, low-income communities are often measured in terms of their earnings, or educational level, which may be deficit areas. From a strengths perspective, low-income communities are measured according to their assets or abilities, which might consist of solid family bonds, a strong work ethic, and informal networking skills (Friedmann, 1992).

One site from Making Connections was bold, and subsequently very successful, in using community strengths to implement the initiative. Each Making Connections site is responsible for a local evaluation of their initiative. One site developed a resident research group (to which we served as advisors) to evaluate local performance. The resident research group is composed of neighborhood residents and carries out the site's research and evaluation activities, a role typically reserved for experts from outside of the community.

Members of the resident research group work on tasks that build on their strengths and interests. For example, one resident utilized her math and computer skills in data 
analysis. This resident researcher works on cleaning and analyzing quantitative data for the initiative. Another resident prefers the one-to-one contact in the community. This resident has been assigned a number of qualitative field interviews.

The concept of utilizing neighborhood strengths has multiple benefits. For one, residents develop an increased investment in the community. Those who work on the resident research group, and those who come in contact with the group, either through participating in interviews, newsletter updates, or in the receipt of additional funding based on positive evaluation outcomes, build an increased sense of pride in the community and are motivated to continue to invest in change efforts. Clearly, for individuals whose strengths can be utilized and fostered, there is a potential for job and career advancement. For example, several resident researchers have been promoted internally to management and program planning positions. As internal promotions occur, new community members are hired on to the resident research group. Finally, the research itself has an authentic perspective from within the community that research performed by outsider researchers can not claim.

\section{Action and Learning}

At its core, it is important to reemphasize that concurrent with the developmental stages of resident participation is an ongoing dynamic process of action and learning that promote adult education. Through action and learning, residents move fluidly between the stages of resident participation toward the dual goals of building community capacity and strengthening neighborhood-based activities. As described in critical learning theory (Mezirow, 1996), this combination of both instrumental and communicative learning through critical reflection creates change and growth both within the individual and the community. Therefore, as a community progresses through the stages of participation, the use and interaction of action and learning are refined.

\section{CRITIQUE AND IMPLICATIONS}

Considering the great potential resident participation has for the success of CCIs and other social work community development efforts, one criticism of the model is that the power differential between funding experts and community residents undermines the substantive contributions and participation of residents. As one resident participating in a CCI put it, "when you get to the table with these outside folks, you are nobody" (Kubisch et al., 2002, p. 37). Our resident participation model seeks to address these power differentials that are omnipresent in change efforts by using the empowering principles of adult learning theory and putting power, skills and learning in the hands of community members.

Garnering resident participation for community initiatives is not a new idea. Many skilled organizers have struggled with the implementation of the participation stages put forth in this model only to see their work undermined by the protocols and regulations of experts and funders. Some organizations have stood their ground and insisted that community change be done their way. Most others have had to find middle ground, 
choosing their battles in order to maintain funding for critical neighborhood programs. This manuscript puts forth a model, or a map, for practitioners who believe that sustainable community change will only be accomplished if led by community residents.

The model is not a panacea. Each stage of the model requires substantial effort and resources and progress will likely not occur in an efficient linear pattern. Instead, real life will get in the way. There will undoubtedly be challenges like when community leaders move, funding gets cut, or the burden of fighting the system leads to burn-out. At the same time there will be successes in the form of a vote won at a town council, rival gang members working along side one another in a co-operative business, or a longtime resident becoming a home owner. All are a part of the process.

In their book, Adult Learning, Citizenship and Community Voices: Exploring Community-Based Practice, Coare and Johnston (2003) discuss the changing role of adult education within a new global economy. In this environment, the authors charge that adult education must respond by teaching diversity, social action and citizenship. Heeding this advice, the participation model in this manuscript presents a framework that can be used as practice guidelines to achieve an inclusive and productive plan for resident participation that can be the foundation for success in a CCI. At the same time, such a model will benefit social work by creating ways in which the field can adjust to new, progressive social movements and engage more non-traditional learners.

\section{References}

Alinsky, S. D. (1971). Rules for radicals: A pragmatic primer for realistic radicals. New York: Vintage Books.

Annie E. Casey Foundation. (2007). Making Connections: A neighborhood transformation family development initiative. Retrieved 1/17/07, from http://aecf.org/initiatives/mc.

Aspen Round Table. (1995). Voices from the field: Learning from the early work of comprehensive community initiatives. Retrieved 1/17/07, from http://www.aspeninstitute.org/site/c.huLWJeMRKpH/b.612045/k.4BA8/Roundtable _ on_Community_Change.htm

Booth, A., \& Crouter, A. C. (2001). Does it take a village? Community effects on children, adolescents, and families. Mahwah: Lawrence Erlbaum Associates.

Bowen, G. L., Martin, J. A., Mancini, J. A., \& Nelson, J. P. (2000). Community capacity: Antecedents and consequences. Journal of Community Practice, 8(2), 1-21.

Brookfield, S. (2005). Learning democratic reason: The adult education project of Jürgen Habermas. Teachers College Record, 107(6), 1127-1168.

Brooks-Gunn, J., Duncan, G. J., \& Aber, J. L. (1997). Neighborhood poverty: Context and consequences for children (Vol. 1). New York: Russell Sage Foundation. 
Brown, P., \& Fiester, L. (2007). Hard lessons about philanthropy \& community change from the Neighborhood Improvement Initiative. Menlo Park, CA: The William and Flora Hewlett Foundation.

Castelloe, P., Watson, T., \& White, C. (2001). Participatory change: An integrative approach to community practice. Asheville, NC: Center for Participatory Change.

Cervero, R. M., \& Wilson, A. L. (1994). The politics of responsibility: A theory of program planning practice for adult education. Adult Education Quarterly, 45(1), 249-268.

Chaskin, R. J. (2001). Building community capacity: a definitional framework and case studies from a comprehensive community initiative. Urban Affairs Review, 36(3), 291-323.

Coare, P., \& Johnston, R. (2003). Adult learning, citizenship and community voices: Exploring community-based practice. Leicester, UK: National Institution of Adult Continuing Education.

Coleman, J. S. (1988). Social capital in the creation of human capital. American Journal of Sociology, 94(Supplement), S95-S120.

DeSouza Briggs, X., \& Muller, E. J. (1996). From neighborhood to community: Evidence on the social effects of community development corporations. New York: Community Development Research Center.

Fals-Borda, O., \& Rahman, M. A. (1991). Action and knowledge: Breaking the monopoly with participatory action research. New York: Apex Press.

Friedmann, J. (1992). Empowerment: The politics of alternative development. Cambridge: Blackwell.

Friere, P. (1994). Pedagogy of the oppressed (M. B. Ramos, Trans. New Revised 20thAnniversary Edition ed.). New York: The Continuum Publishing Company.

Gamble, D. N., \& Weil, M. O. (1995). Citizen participation. In R. L. Edwards (Ed.), Encyclopedia of social work (19 ${ }^{\text {th }}$ ed., Vol. 1, pp. 483-494). Washington, DC: NASW Press.

Glickman, N. J., \& Servon, L. J. (1998). More than bricks and sticks: Five components of community development corporation capacity. Housing Policy Debate, 9(3), 497539.

Gramsci, A. (1986). Selections from the prison notebook of Antonio Gramsci. (Q. Hoare \& G. Nowell Smith, Eds. \& Trans.). London: Lawrence and Wishart.

Hill, D.M. (1994). Citizens and cities. London: Harvester Wheatsheaf.

Jencks, C., \& Mayer, S. E. (1990). The social consequences of growing up in a poor neighborhood. In L. E. Lynn \& M. G. H. McGeary (Eds.), Inner-city poverty in the United States (pp. 111-186). Washington, DC: National Academy Press. 
Joassart-Marcelli, P. M., Musso, J. A., \& Wolch, J. R. (2005). Fiscal consequences of concentrated poverty in a metropolitan region. Annals of the Association of American Geographers, 95(2), 336-356.

Johnston, R. (1999). Adult learning for citizenship: Towards a reconstruction of the social purpose tradition. International Journal of Lifelong Education, 18(3), 175-190.

Johnston, R. (2000). Community education and lifelong learning. In J. Field \& M. Leicester (Eds.) Life learning: Education across the lifespan (pp 12-28). London: Routledgefalmer.

Kahn, S. (1995). Community organization. In R. L. Edwards (Ed.), Encyclopedia of social work (19th ed., Vol. 1, pp. 569-576). Washington, DC: NASW Press.

Kretzmann, J. P., \& McKnight, J. L. (1993). Building communities from the inside out: A path toward finding and mobilizing a community's assets. Chicago: ACTA Publications.

Kubisch, A. (1996). Comprehensive community initiatives: Lessons in neighborhood transformations. Shelterforce Online.

Kubisch, A. C., Auspos, P., Brown, P., Chaskin, R., Fulbright-Anderson, K., \& Hamilton, R. (2002). Voices from the field II: Reflections on comprehensive community change. Washington, DC: The Aspen Institute.

Leach, M. (1994). Building capacity through action learning. Institute for Development Research Reports, 10(5), 1-29.

Lewin, K. (1946). Action research and minority problems. Journal of Social Issues, 2, 34-46.

Massey, D. S. (1990). American apartheid: Segregation and the making of the underclass. The American Journal of Sociology, 96, 329-57.

Mayo, M. (1997). Imagining tomorrow: Adult education for transformation. Leicester: NIACE.

McTaggart, R. (Ed.). (1997). Participatory action research: International contexts and consequences. Albany: State University of New York Press.

Medoff, P., \& Sklar, H. (1994). Streets of hope: The fall and rise of an urban neighborhood. Boston: South End Press.

Mezirow, J. (1996). Contemporary paradigms of learning. Adult Education Quarterly, 46(3), 158-173.

Nesbit, T. (2006). What's the matter with social class? Adult Education Quarterly, 56(3), 171-187.

Newman, M. (1995). 'Locating learning in social action' Social action and emancipatory learning. Paper presented at the Seminar Papers, School of Adult Education, Sydney. 
O'Connor, A. (1999). Swimming against the tide: A brief history of federal policy in poor communities. In R. F. Ferguson \& W. T. Dickens (Eds.), Urban problems and community development (pp. 77-138). Washington, DC: The Brookings Institution.

Putnam, R. D. (2000). Bowling alone: The collapse and revival of American community. New York: Simon \& Schuster.

Quillian, L. \& Redd, R. (2006). Can social capital explain persistent poverty gaps? National Poverty Center Working Papers Series, \#06-12.

Rohe, W. M. (1999). Do community development corporations live up to their billing? A review and critique of the research findings. In T. Koebel (Ed.), Shelter and society: Theory research and policy for non-profit housing (pp. 177-200). Albany, NY: State University of New York Press.

Rohe, W. M., Bratt, R. G., \& Biswas, P. (2003). Evolving challenges for community development corporations: The causes and impacts of failures, downsizings and mergers. Chapel Hill: University of North Carolina.

Roundtable on Community Change. (2008). Retrieved 10/20/08, from http://www.aspeninstitute.org/site/c.huLWJeMRKpH/b.612045/k.4BA8/Roundtable on Community Change.htm

Rubin, H. J. (2000). Renewing hope within neighborhoods of despair: The communitybased development model. Albany: State University of New York.

Saleebey, D. (1997). The strengths perspective in social work practice (2nd ed.). New York: Longman.

Sampson, R. J., Raudenbush, S. W., \& Earls, F. (1997). Neighborhoods and violent crime: A multilevel study of collective efficacy. Science, 277(5328), 918-924.

Sarri, R. C., \& Sarri, C. M. (1992). Organizational and community change through participatory action research. Administration in Social Work, 16(3/4), 99-122.

Schleifer, J. T. (1991). Jefferson and Tocqueville. In K. Masugi (Ed.), Interpreting Tocqueville's democracy in America (pp. 178-203). Savage, MD: Rowman \& Littlefield.

Selman, G., Selman, M., Cooke, M. \& Dampier, P. (1998). Terms and functions. In The foundations of adult education in Canada. Toronto: Thompson Educational Publishing.

Thompson, D. F. (1976). John Stuart Mill and representative government. Princeton, NJ: Princeton University Press.

Twelvetrees, A. C. (1996). Organizing for neighbourhood development: A comparative study of community based development organizations. Brookfield: Avebury.

U. S. Census Bureau. (2007). American Community Survey Homepage. Retrieved February 5, 2008, from http://www.census.gov/acs/www/index.html 
Weick, A., Rapp, C., Sullivan, W. P., \& Kisthardt, W. (1989). A strengths perspective for social work practice. Social Work, 34(4), 350-354.

Weil, M. O., \& Gamble, D. N. (1995). Community practice models. In R. L. Edwards (Ed.), Encyclopedia of social work $\left(19^{\text {th }}\right.$ ed., Vol. 1, pp. 577-594). Washington, DC: NASW Press.

Welton, M. (1997). Repair, defend, invent: Civil societarian adult education faces the twenty-21st century. In O. Korsgaard (Ed.) Adult learning and the challenges of the 21st century (pp.67-75). Odense: Association for World Education.

Wilkinson, P., \& Quarter, J. (1995). A theoretical framework for community-based development. Economic and Industrial Democracy, 16, 525-551.

Wilson, W. J. (1987). The truly disadvantaged. Chicago: University of Chicago Press.

\section{Author's note:}

Address correspondence to: Daniel Brisson, Ph.D., Graduate School of Social Work, University of Denver, 2148 High Street, Denver, CO 80208. Email:

daniel.brisson@du.edu. 